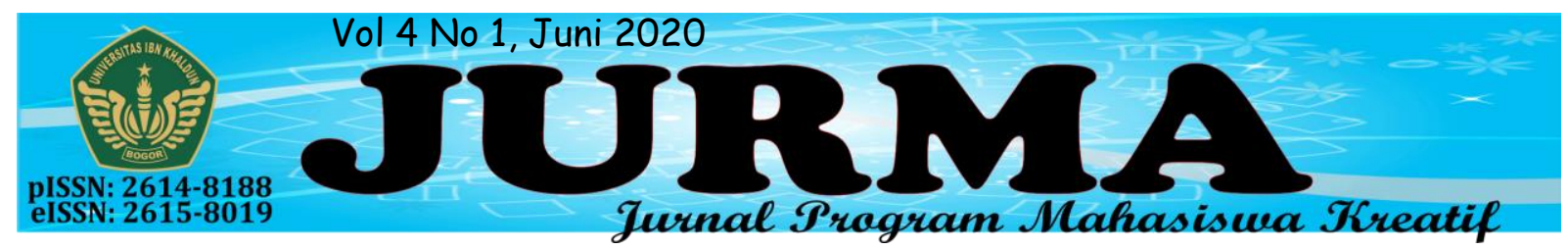

\title{
PERGERAKAN KELOMPOK TERORIS THE RED BRIGADES DI ITALIA TAHUN 1968 - 2004
}

\author{
Desty Amalia Putri, Anisa Fahri, Dea Puspita, Meisya Rizkiya \\ destyamaliaputri@student.untan.ac.id \\ Fakultas Ilmu Sosial dan Politik, Universitas Tanjungpura
}

\begin{abstract}
ABSTRAK
Tulisan ini bertujuan untuk membahas tentang pergerakan kelompok The Red Brigades dalam melakukan aksi terornya di Italia periode tahun 1968-2004. Banyak kelompok sayap kiri yang muncul karena adanya krisis ekonomi yang terjadi pada saat itu dan anggapan bahwa pemerintah Italia yang cenderung condong ke Amerika Serikat yang terkenal sebagai negara kapitalis. Red Brigades adalah salah satu dari sekian banyak kelompok sayap kiri yang muncul karena adanya krisis ekonomi dan juga kesenjangan sosial. Dengan berjalannya waktu, tujuan utama Red Brigades yang awalnya memfokuskan kepada kesejahteraan masyarakat menengah ke bawah lama kelamaan menjadi ambigu. Para pemimpin Red Brigades menjadikan kesempatan ini untuk menghancurkan pemerintahan dan menjadikan Italia sebagai negara yang menganut paham komunisme. Tulisan ini menjelaskan bagaimana awal kemunculan kelompok teroris Red Brigades mampu menggoyahkan pemerintah Italia sampai akhirnya mereka memutuskan untuk bubar. Penulis menggunakan teori rational choice dan konsep kelompok kepentingan untuk menganalisis kasus. Teknik yang dipergunakan adalah studi dokumen dan penelusuran literatur atau dengan menggunakan studi kepustakaan. Studi dokumen dan penelusuran literature ini merupakan suatu alat pengumpulan data yang melalui data tertulis. Hasil dari tulisan ini menunjukan bahwa bagaimana Red Brigades telah menjadi kelompok terorisme yang anarkis yang menjadikan kesenjangan sosial sebagai alasannya.
\end{abstract}

Kata Kunci: Red Brigades, Italia, Terorisme, Komunisme, Kelompok Sayap Kiri.

\section{PENDAHULUAN}

\section{Latar Belakang}

The Red Brigades adalah suatu kelompok militan yang muncul pada 20 Oktober 1970 yang diinisiasikan oleh mahasiswa aktivis Universitas Trento bernama Renato Curcio, Mara Cagol, dan Alberto Franceshini. Kelompok ini dibentuk pada tahun 1968 di Milan, dengan harapan mereka dapat menyampaikan aspirasinya untuk berpartisipasi, keadilan dan kebebasan dalam politik. Mereka mendapatkan dukungan yang besar dari kaum pekerja buruh dan pekerja lokal. Pada masa itu merupakan kesempatan tebesar bagi kaum menengah ke bawah untuk menyampaikan aspirasinya, sehingga Red Brigades berusaha untuk menyampaikan aspirasi dari kaum menengah ke bawah serta mencari keadilan dan kebebasan dalam berpolitik. ${ }^{1}$

${ }^{1}$ Paul Ginsborg. A History of Contemporary Italy: Society and Politics: 1943-1988. Inggris: Penguin UK, 1990. Hal. 361 
Awalnya Red Brigades melakukan kegiatan yang di anggap mendukung aspirasi masyarakat dengan tujuan utama menghilangkan kesenjangan sosial namun setelah beredarnya berita mengenai keberhasilan revolusi kebudayaan di China, arah dan tujuan Red Brigades menjadi ambigu. Red Brigades yang semakin berjalan waktu didominasi oleh kaum komunis muda menganggap bahwa mereka dapat mengubah Italia menjadi negara yang maju. Mereka berusaha menciptakan negara revolusioner melalui perjuabgan bersenjata dan untuk menyingkiran Italia dari Organisasi Perjanjian Atlantik Utara. Satusatunya cara yang di anggap Red Brigades efektif adalah dengan menghilangkan para elit-elit pemeritahan dan penguasa dan juga para pelayan imperialis. Mereka menganggap kaum ini yang menghambat perkembangan negara Italia untuk menjadi maju karena perilaku semena-mena mereka. Dengan konsep ini Red Brigades yang awalnya melakukan kegiatan yang damai perlahan menjadi anarkis, mereka menargetkan para buruh dan kaum menengah ke bawah menjadi anggotanya.

Mereka menarik para kaum menegah ke bawah dan memengaruhi mereka sehingga mereka melakukan kegiatan yang anarkis guna menghilangkan para penguasa dan petinggi yang mereka anggap harus dimusnahkan. Selain itu, Red Brigades bertanggung jawab atas 145 kasus pembunuhan dan kekacauan yang terjadi di Italia pada tahun 1970 hingga awal 1980an. Mereka melakukan gerakan untuk mengguncang Italia dengan tindakan sabotase, perampokan, penculikan hingga pembunuhan. ${ }^{2}$ Penculikan pertama yang

\footnotetext{
2 Alessandro, Orsini. Sarah J Nodes. Anatomy of the Red Brigades: The Religious Mind-set of Modern Terrorists. Ithaca: Cornell University Press. 2011.

3 Ginsborg, "A History of Contemporary Italy: Society and Politics: 1943-1988. Hal. 361-362
}

dilakukan oleh Red Brigades adalah pada tahun 1972, mereka menculik mandor pabrik Sit Siemens dan ditahan selama setengah jam kemudian mengambil foto dengan mengenakan papan penanda yang menyatakan bahwa dirinya seorang penganut fasis. Kemudian mandor tersebut dilepaskan tanpa ada luka sedikitpun.

Kelompok Red Brigades sebenarnya dikecam oleh para kelompok sayap kiri, walaupun para petinggi Red Brigades menyatakan bahwa mereka mendapatkan dukungan yang besar dari orang orang sayap kiri tetapi orang saya kiri membantah pernyataan tersebut. Pernyataan ini dipicu oleh tewasnya dua anggota partai Neo-Fasis Italisa, Movimento Sociale Italiano (MSI). Namun publik lebih percaya dengan pernyataan dari Red Brigades karena hal ini di dukung fakta bahwa banyak anggota Red Brigades berada dalam struktur militer Itaia.

Pada dasarnya gerakan mereka adalah gerakan yang terpengaruhi oleh gerakan perlawanan partisan Italia pada tahun 1940an. Yang dijelaskan sebagai gerakan minoritas muda anti-asil dengan cara kekerasan namun untuk tujuan yang adil. ${ }^{3}$ Salah satu gerakan Red Brigades yang paling terkenal adalah penculikan Perdana Menteri Aldo Moro di bawah kepemimpinan Mario Moretti. ${ }^{4}$ Pada saat itu Aldo Moro sedang melakukan perundingan mengenai Kompromi storico atau Kompromi bersejarah dengan komunis. Mereka membunuh lima pengawal Aldo Moro dan menyekapnya. Mereka berusaha melakukan negosiasi dengan membebaskan Moro secara aman namun dengan kompensasi yang

\footnotetext{
4 "Brigate Rosse and Moro Kidnapping: Secrets and Lies" http://www.robertobartali.it. Diakses 9 Juni 2020. http://www.robertobartali.it/english.htm
} 
ditentukan. Tetapi pemerintah Italia tidak ingin melakukan negosiasi. Setelah menyadari bahwa pemerintah tidak akan mau bernegosiasi mereka memutuskan untuk membunuh Aldo Moro setelah ditahan selama 55 hari. Hal ini dilakukan sebagai upaya agar tidak ketahuan. Akibat aksi ini Red Brigades mendapat kecaman dan kehilangan dukungan terbesarnya bahkan pendiri Red Brigades sendiri yang saat itu sedang di penjara memberikan kecaman terhadap aksi ini. ${ }^{5}$ Sehubungan dengan uraian di atas perlu kiranya kita mengkaji lebih dalam mengenai pergerakan kelompok teroris Red Brigades di Italia. Sehingga penulis berniat dan tertarik mengangkat sebuah penelitian dengan judul

\section{METODE PENELITIAN}

Metode yang digunakan dalam penelitian ini adalah metode penelitian deskriptif. Penulis dalam hal ini memaparkan perkembangan terkait aksi terorisme yang dilakukan oleh kelompok Red Brigades di Italia dari tahun 19682004. Teknik yang dipergunakan adalah studi dokumen dan penelusuran literatur atau dengan menggunakan studi kepustakaan. Studi pustaka menempati posisi yang sangat penting dalam penelitian. Walaupun sebagian orang membedakan antara riset kepustakaan dan riset lapangan, akan tetapi keduaduanya memerlukan penelusuran pustaka. Ada perbedaan yang melekat pada riset kepustakaan dengan riset lapangan,

\footnotetext{
5 "Remembering Aldo Moro, the former prime minister killed by terrorists during Italy's 'Years of Lead'." thelocal.it, diakses 20 Mei 2020. https://www.thelocal.it/20180315/italy-remembersaldo-moro
}

Pergerakan Kelompok Teroris The Red Brigades di Italia Tahun 1968 - 2004.

\section{Pertanyaan Penelitian}

Berdasarkan uraian latar belakang tersebut, maka dapat diperoleh pertanyaan penelitian sebagai berikut sebagai berikut:

1. Bagaimana perkembangan kelompok teroris Red Brigades selama melaksanakan aksinya?

2. Bagaimana upaya pemerintahan Italia dalam memberantas kelompok teroris Red Brigades?

3. Apa yang menjadi faktor pemberontakan yang dilaksanakan oleh kelompok Red Brigades?

perbedaannya yang utama adalah terletak pada tujuan, fungsi atau kedudukan studi pustaka dalam masing-masing penelitian tersebut. Riset lapangan, penelusuran pustaka sebagai langkah awal dalam rangka untuk menyiapkan kerangka penelitian yang bertujuan memperoleh informasi penelitian sejenis, memperdalam kajian teoritis. ${ }^{6}$

Studi dokumen dan penelusuran literature ini merupakan suatu alat pengumpulan data yang melalui data tertulis. Metode studi dokumen dan penelusuran literatur atau studi kepustakaan ini dilakukan untuk mendapatkan bahanbahan hukum sebagai bahan utama dalam penelitian ini. ${ }^{7}$

\footnotetext{
${ }^{6}$ Khotibah. "Penelitian Kepustakaan." Volume 05. No.01. 2011. Hal 38

7 S. Nasution. Metode Penelitian Naturalistik Kualitatif. Bandung: Tarsito, 1988. Hal 129-130.
} 


\section{TINJAUAN PUSTAKA}

\section{Kerangka Teori Dan Konsep}

Penulis menggunakan teori rational choice dan konsep kelompok kepentingan. Teori rational choice digunakan penulis untuk menjelaskan kebijakan yang diambil oleh kelompok Red Brigades dalam menyampaikan aspirasinya tentang keadilan dan berupaya mempengaruhi kebijakan pemerintah supaya tidak kearah barat. Kemudian teori rational choice juga digunakan untuk menjelaskan kebijakan yang diambil oleh pemerintah Itali untuk memberantas kelompok teroris Red Brigades. Selain itu, penulis juga menggunakan konsep kelompok kepentingan untuk menjelaskan alasan kelompok Red Brigades melakukan aksi terorisme di Italia.

\section{Teori Rational Choice}

Teori rational choice muncul karena adanya keputusan yang harus diambil oleh setiap individu, kelompok, maupun negara. Keputusan yang akan diambil harus mempertimbangkan semua pilihan yang ada, seperti mempertimbangkan biaya yang akan dikeluarkan, keuntungan, serta kerugian yang akan didapatkan dari keputusan yang akan diambil.

Menurut John Scoot, rational choice merupakan sebuah teori yang menjelaskan tentang tindakan rasional yang ada di dalam setiap karakter masing-masing individu. Tindakan rasional digunakan untuk berfikir sebelum memutuskan tindakan apa yang harus dilakukan dengan mempertimbangkan keuntungan, serta kerugian yang akan didapatkan. Pengalaman masa lalu juga dapat menjelaskan dan memiliki pengaruh bagi

\footnotetext{
8 Enggar Swastika. "Kebijakan Perdana Menteri Yingluck Shinawatra Tentang Pembatalan Ekspor Beras Ke Indonesia Tahun 2011" Thesis, UMM Instutional Repository, 2016: 16.
}

setiap pengambil keputusan. Dimana pengambil keputusan memiliki pengalaman yang membuat mereka belajar dari pengalaman tersebut, sehingga mereka mengetahui keputusan terbaik yang harus diambil untuk kedepannya. ${ }^{8}$

Kemudian menurut Stephen $M$. Waltz, teori rational choice terbagi menjadi tiga sifat. Pertama, rational choice bersifat individu, dimana hasil dari sosial dan politik di pandang sebagai produk kolektif atas pilihan individu atau dapat diartikan sebagai produk yang dibuat oleh pembuat keputusan. Kedua, pembuat keputusan berusaha untuk memaksimalkan hasil yang akan didapatkan dari keputusan yang diambilnya. Ketiga, berupaya untuk menspesifikan preferensi dari pembuat keputusan terhadap kendala tertentu, misalnya saja pembuat keputusan memiliki beberapa pilihan. Pilihan tersebut harus bersifat transitif misalnya jika pilihan A lebih dinilai penting dibandingkan dengan pilihan $\mathrm{B}$ dan $\mathrm{C}$, makanya pembuat keputusan harus memilih pilihan A. ${ }^{9}$

Dalam membuat dan mengambil keputusan, pembuat keputusan harus berusaha untuk meminimalkan biaya yang akan dikeluarkan, serta menekan kerugian yang akan didapatkan dan berusaha untuk memperoleh keuntungan sebanyakbanyaknya. Dimana pembuat keputusan harus dapat bertindak untuk dapat membandingkan setiap pilihan yang ada. ${ }^{10}$

Dalam penelitin ini, penulis menggunakan teori rational choice untuk melihat kelompok teroris Red Brigades mengambil kebijakan melakukan aksi terorisme di Itali. Pada awalnya kelompok

\footnotetext{
${ }^{9}$ Stephen M. Waltz. Rational Choice and Security Studies: Rigor or Rigor Moris?. Massachusetts: MIT Press Journals, 1999

${ }^{10}$ Swastika, "“'Kebijakan Perdana Menteri Yingluck Shinawatra Tentang Pembatalan Ekspor Beras Ke Indonesia Tahun 2011”, 16
} 
Red Brigades terbentuk dari golongan mahasiswa dan pekerja yang merasa mendapatkan perlakuan tidak adil, dimana kaum Borjuis bertindak semaunya. Kelompok Red Brigades juga berusaha untuk mempengaruhi kebijakan pemerintah Itali yang mulai lebih kearah barat. Dalam mengambil kebijakan, Red Brigades mempertimbangkan keuntungan dan kerugian yang akan didapatkan oleh kelompoknya. Demi mencapai tujuannya kelompok Red Brigades mengambil kebijakan untuk melakukan aksi terorisme di Italia, teror yang dilakukan seperti pencurian, pembunuhan, penculikan dan pengeboman. Kegiatan terorisme yang mereka lakukan supaya pemerintah memandang dan menuruti keinginan mereka.

Pengalaman juga mempengaruhi dalam mengambil kebijakan, dimana pada awalnya kelompok Red Brigades hanya melakukan pencurian. Tetapi seiring berjalannya waktu untuk mempengaruhi kebijakan pemerintah kelompok Red Brigades melakukan aksi yang meresahkan masyarakat Italia seperti melakukan penculikan, pembunuhan dan pengeboman yang merusak beberapa fasilitas umum.

Kemudian dalam penelitian ini, penulis menggunakan teori rational choice juga untuk melihat kebijakan-kebijakan yang diambil oleh pemerintah Itali untuk memberantas aksi teror yang dilakukan oleh Red Brigades. Dalam mengambil kebijakan pemerintah Italia mempertimbangkan keuntungan, serta kerugian dan berupaya meminimalkan biaya. Pengalaman juga mempengaruhi kebijakan yang akan diambil oleh pemerintah Itali, dimana pemerintah Italia semakin bertahap mengeluarkan kebijakan yang benar-benar serius untuk memberantas aksi terorisme kelompok Red Brigades yang semakin meresahkan masyarakat Italia. Kebijakan yang diambil oleh pemerintah Italia termasuk ke dalam salah satu sifat dari teori rational choice, yaitu sifat kedua. Dimana sifat kedua yaitu pembuat keputusan berusaha untuk memaksimalkan hasil yang akan didapatkan dari keputusan yang diambilnya. Pemerintah Italia dalam mengambil kebijakan benar-benar berupaya melakukan yang terbaik, supaya mendapatkan hasil yang maksimal untuk memberantas kelompok teroris Red Brigades.

Kebijakan yang diambil pemerintah Italia antara lain yaitu pertama membentuk Gladio yang terdiri dari sekelompok unit militer yang akan dikerahkan saat terjadi pemberontakan komunis di Italia dan berupaya mengembalikan Italia ke jalur demokratisnya. Kedua, adanya kelompok polisi yang terlibat dengan nama Pubblica Sicurezza (PS) dan Armata de i Carabinieri (CC). Ketiga, dinas rahasia mengembangkan dua lembaga khusus yang bernama Inspektorat Jendral yang berfungsi untuk melawan aksi teroris yang disebut dengan Ispettorato General per la Lotta Contro i terror-ismo dan membentuk kelompok khusus Judiciary Police yang disebut dengan Nucleo Speciale di Polizia Quardiziaria yang berhasil menghancurkan kelompok teroris sayap kiri, serta menangkap pendiri Red Brigades yaitu Renato Curcio dan Alberto Franceschini. Keempat, mengeluarkan Undang-Undang Pentiti yang menangani ancaman teroris secara langsung untuk mencegah kejahatan dimasa depan, serta Undang-Undang Pentiti mengatur tentang hukuman bagi para teroris. Hukuman bagi para teroris akan dikurangi jika mereka meninggalkan perjuangan bersenjata dan tidak bekerjasama lagi, serta memberi informasi tentang teroris. Undang-Undang Pentiti 
juga mengatur tentang memberikan pelatihan profesional kepada pelaku terorisme untuk dapat kembali ke masyarakat.

\section{Konsep Kelompok Kepentingan}

Kelompok kepentingan muncul didasarkan pada kesamaan kepentingan yang dimiliki oleh setiap individu yang ada di sebuah kelompok, sehingga saling bersatu demi tercapainya kepentingan yang menguntungkan bagi mereka. Kelompok kepentingan digunakan sebagai sebuah sarana untuk mempengaruhi proses pengambilan kebijakan suatu negara.

Kelompok kepentingan merupakan sekumpulan orang yang memiliki kesamaan dari segi kepercayaan akan suatu hal, sifat dan sikap yang sama, serta berupaya untuk mencapai tujuannya. Kelompok kepentingan juga termasuk kedalam kelompok yang terorganisasi, dimana di dalam kelompok kepentingan terdapat sistem keanggotaan yang jelas, serta memiliki pola kepemimpinan. ${ }^{11}$

Menurut Grabriel Almond, kelompok kepentingan dapat dibedakan menjadi empat tipe berdasarkan gaya dan metode dalam mengajukan sebuah kepentingan. Tipe pertama yakni kelompok kepentingan anomik, kelompok kepentingan ini mengajukan kepentingannya secara spontan dan berorientasi pada tindakan yang dilakukan secara segera. Tipe pertama disebut sebagai kelompok anomik karena memiliki identitas yang kurang jelas. Tindakan yang dapat dilakukan untuk memperjuangkan kepentingan antara lain seperti demonstrasi, huru-hara dan pemogokan. Tipe yang kedua disebut

\footnotetext{
${ }^{11}$ Efri Aditya Putra. "Persaingan Global Climate Coalition dan Greenpeace dalam Mempengaruhi Kebijakan Amerika Serikat Terhadap Ratifikasi Protokol Kyoto" Thesis, UMM Instutional Repository, 2016: 19-20

12 Putra, "Persaingan Global Climate Coalition dan Greenpeace dalam Mempengaruhi Kebijakan Amerika Serikat Terhadap Ratifikasi Protokol Kyoto", 20
}

dengan kelompok kepentingan nonasosiasi, kelompok kepentingan ini terbentuk karena adanya terdapat kepentingan yang sama, sehingga samasama berusaha untuk memperjuangkannya. Kemudian kelompok ini biasanya menggunakan cara-cara pendekatan yang bersifat informal kepada pemerintah dalam memperjuangkan kepentingannya. ${ }^{12}$

Selanjutnya ada tipe ketiga yang disebut dengan kelompok kepentingan institusional, kelompok kepentingan tipe ini muncul di dalam lembaga-lembaga politik dan pemerintah yang berfungsi bukan hanya untuk mengartikulasikan kepentingan. Kelompok kepentingan ini menduduki posisi-posisi penting, sehingga mereka dapat berpengaruh terhadap proses penyusunan kebijakan yang sangat besar, tetapi mereka cenderung melayani kepentingan sendiri. Kelompok kepentingan institusional seperti kelompok tertentu di dalam angkatan bersenjata, birokrasi dan partai politik. Tipe keempat atau yang terakhir disebut dengan kelompok kepentingan asosiasional, kelompok kepentingan ini terorganisasi dengan baik dan terus menerus menjalin hubungan dengan para anggota dan menjalin hubungan dengan pemerintah. Dimana, kelompok kepentingan ini secara khusus berfungsi untuk mengartikulasikan kepentingan kelompok. Kelompok yang termasuk kedalam kepentingan asosiasional seperti Himpunan Petani, Ikatan Dokter, Kamar Dagang dan Industri, serta Serikat Pekerja. ${ }^{13}$

Dalam penelitian ini, penulis menggunakan konsep kelompok

\footnotetext{
${ }^{13}$ Ramlan Surbakti, "Memahami Ilmu Politik”, (Grasindo. PT. Gramedia) Hal: 109. E-Book.
} 
kepentingan untuk melihat alasan pembentukan kelompok teroris Red Brigades di Italia. Kelompok Red Brigades terbentuk karena adanya kesamaan dari segi kepercayaan, sifat dan sikap yang dimiliki oleh anggotanya. Kelompok Red Brigades dibentuk dari golongan pekerja dan mahasiswa yang ingin menyampaikan aspirasi, serta ingin mendapatkan keadilan dan berusaha untuk dapat mempengaruhi kebijakan pemerintah di Italia yang lebih kearah barat pada saat itu.

Kelompok Red Brigades juga termasuk ke dalam salah satu tipe kelompok kepentingan yaitu tipe kedua. Tipe kedua yang disebut dengan kelompok kepentingan

\section{PEMBAHASAN}

\section{Enam Fase Kelompok Red Brigades \\ 1. Development Phase}

\section{A. Aksi Protes Oleh Kaum Pekerja Dan Mahasiswa}

Lima puluh tahun yang lalu, terdapat banyak protes disuarakan di negara-negara Eropa. Kebanyakan mengetahui gerakan protes yang terjadi di Perancis. Tapi aksi protes terpanjang dan paling kompleks sebenarnya terjadi di Italia pada tahun 1968, pada saat itu Italia sedang dilanda krisis ekonomi yang belum pernah terjadi sebelumnya. Di antara orang Italia, ada sedikit kesepakatan tentang kapan protes 1968 dimulai atau kapan mereka berakhir. Di beberapa kota, protes mahasiswa dimulai dua tahun sebelumnya. Bagi kebanyakan orang, itu adalah awal dekade konfrontasi ideologis yang traumatis dan juga penuh dengan kekerasan. Semua setuju, bahwa 1 Maret 1968, telah mengambil status mitologis. Pada periode ini terjadi pertempuran Valle Giulia, yang

14 “Valle Giulia Has Taken On Mythological Stature." npr.org, diakses 17 Mei 2020. non-asosiasi ini dapat menjelaskan bahwa Red Brigades terbentuk karena adanya terdapat kepentingan yang sama, sehingga kelompok Red Brigades berusaha untuk memperjuangkan kepentingannya seperti mendapatkan keadilan dan mempengaruhi kebijakan pemerintah Italia. Dalam mencapai tujuannya untuk mempengaruhi kebijakan pemerintah kelompok Red Brigades melakukan pendekatan secara informal atau tidak resmi kepada pemerintah yaitu dengan melakukan aksi teror berupa penculikan, perampokan, pembunuhan, serta pengeboman yang meresahkan masyarakat Italia.

terjadi di depan Universitas Roma. Sekitar 4.000 siswa menghadapi polisi di sekitar gedung. Merupakan bentrokan keras karena sekitar 150 polisi dan 500 siswa terluka. ${ }^{14}$

Italia diketahui memiliki Partai Komunis terbesar di antara negara-negara barat lainnya. Banyak aktivis 1968 yang beragama katolik militan yang menemukan kekuatan revolusioner Injil dan merangkul perjuangan buruh. Ketika gerakan itu terjadi hingga 1969, suasana protes melanda pabrik. Buruh memberontak melawan serikat tradisional dan melakukan mogok kerja untuk total 238 juta jam kerja. Pada saat musim panas tahun 1969, ratusan ribu pekerja dan mahasiswa berbaris bersama menuntut perlakuan terhadap pekerjaan yang lebih baik dan meneriakkan slogan-slogan anti-kapitalis. Klimaksnya terjadi pada 12 Desember 1969, sebuah bom meledak di sebuah bank di Milan, menewaskan 16 orang dan melukai 90 orang. Peristiwa yang dinamakan Bom

https://www.npr.org/templates/story/story.php?storyId=9181908 
Piazza Fontana tersebut mengantar apa yang kemudian dikenal sebagai tahun-tahun dimana gelombang terorisme sayap kanan dan kiri mulai bermunculan. Beberapa bulan setelah pemboman bank, sekelompok mahasiswa Katolik dari Universitas Trento mendirikan kelompok yang dikenal dengan nama Red Brigades. ${ }^{15}$

\section{B. Terbentuknya The Red Brigades}

Setelah Italia mengalami gejolak akibat perekonomiannya yang tidak stabil, pada saat ini juga mulai banyak bermunculan kelompok-kelompok yang menginginkan adanya revolusi di negara ini. Red Brigades atau yang lebih sering disebut dalam bahasa Italia sebagai Brigate Rosse (BR), secara resmi dibentuk pada 20 Oktober 1970 oleh mahasiswa aktivis Universitas Trento, Renato Curcio bersama dengan pasangannya Mara Cagol dan teman aktivisnya Alberto Franceschini. Kelompok Red Brigades ini muncul dari barisan dan gerakan protes pekerja dan mahasiswa tahun 1960-an di mana mereka mengklaim dukungan untuk serikat buruh lokal dalam perjuangan melawan kaum politik borjuis sayap kanan. Red Brigades awalnya mengarahkan upaya mereka di kota-kota besar Italia seperti Milan dan Turin dimana mereka memandang diri mereka sebagai bagian dari gerakan ekstra-parlementer Autonomia Operaia (AO). Bertindak sebagai faksi dari gerakan politik yang lebih besar dan terfragmentasi ini, para pemimpin kelompok cenderung menyebarkan pemahamannya di pabrik-pabrik, di mana kesenjangan sosial lebih jelas dan perselisihan perburuhan lebih akut. Para pemimpin kelompok merencanakan

\footnotetext{
${ }^{15}$ Victor H. Sundquist. "Political Terrorism: An Historical Case Study of the Italian Red Brigades" Journal of Strategic Security (2010): 55. doi: http://dx.doi.org/10.5038/1944-0472.3.3.5

16 "Red Brigades" britannica.com. Diakses 1 Juni 2020. https://www.britannica.com/topic/Red-Brigades

${ }^{17}$ Carole Beebe Tarantelli. "The Italian Red Brigades and the structure and dynamics of terrorist groups" The International
}

penciptaan negara revolusioner melalui penggunaan senjata untuk menciptakan pemisahan antara Pemerintah Italia yang baru dan Aliansi Barat lainnya. Selain melakukan pengeboman, para pemimpin kelompok melakukan protes dan penghinaan atas perlakuan pimpinanpimpinan serikat pekerja-pekerja pabrik, serta kapitulasi pemerintah dalam memecahkan masalah sosial.

\section{Serangan ke Pabrik-Pabrik di Italia (1970-1971)}

Red Brigades menyatakan kelompok mereka sebagai garda depan gerakan buruh dan mulai melakukan 'propaganda bersenjata', yang termasuk menculik, melukai, dan menghancurkan tujuan pemerintah. Maksud dari tindakan mereka adalah untuk "menyerang jantung negara", dan mereka menganggap bahwa ini akan meradikalisasi gerakan dan menciptakan kondisi untuk perang saudara secara berkelanjutan, yang pada gilirannya akan mengarah pada penggulingan negara yang saat itu condong ke kapitalis dengan maksud untuk menciptakan masyarakat komunis. ${ }^{16}$ Red Brigades memproklamirkan keberadaannya pada bulan November 1970 melalui pengeboman berbagai pabrik dan gudang di Milan. ${ }^{17}$ Selanjutnya anggota Red Brigades melakukan tindakan sabotase terhadap pekerja yang dilaksanakan di dalam pabrik, kegiatan ini juga disertai dengan perusakan truk-truk milik pabrik-pabrik yang menjadi incaran kelompok Red brigades. Para pekerja pabrik kemudian diintrogasi secara intens guna mengetahui aktivitas mereka di dalam pabrik. ${ }^{18}$

\footnotetext{
Journal of Psychoanalysis (2016): 545. doi: 10.1111/j.17458315.2010.00264.x

18 Matteo RE. "Colpevolezza Ed Esagerazione Nell'interpretazione Del Terrorismo Brigatista Da Parte Della Stampa Italiana”. (2011): 165. doi: http://dx.doi.org/10.5209/rev_CFIT.2011.v18.38169
} 
2. Initial Activity Phase (1972-1976)

A. Penculikan Karyawan Pabrik Sit Siemens (1972)

Pada tanggal 17 September, kelompok Red Brigades melakukan penculikan. Mereka melakukan serangan pembakaran untuk yang pertama kalinya, mereka membakar garasi manajer HR SitSiemens lalu menculiknya. Mereka kemudian melakukan serangan pembakaran yang lebih hebat lagi di Pirelli, yang dilakukan oleh Franceschini dan tiga pekerja pabrik, yang memicu ledakan yang hebat. Karena hal ini juga mereka berhasil menghancurkan enam truk dan menyebabkan kerusakan yang signifikan. Selama periode ini, anggota kelompok Red Brigades sangat membanggakan diri karena menganggap aksi yang mereka lakukan berhasil dan tidak lebih kejam dibandingkan aksi-aksi banyak kelompok teroris yang muncul lainnya. Kelompok Red Brigades juga melakukan perampokan dan penculikan untuk mendanai aksi teror mereka dan memperoleh senjata dari pasar gelap dan senjata Partisan yang tersisa dari Perang Dunia Kedua. ${ }^{19}$

\section{B. Penyebaran Doktrin dan Penangkapan Curcio dan Franceshini (1974-1975)}

Dari tahun 1970-1974, pemerintah Italia sangat meremehkan keberadaan kelompok Red Brigade dan masalah terorisme yang terjadi di negara tersebut, meskipun ada beberapa serangan besar yang dilakukan oleh kelompok-kelompok teroris sayap kanan selama periode ini, serangan-serangan teror kadang-kadang melibatkan anggota polisi dan agen rahasia, dan untuk memperburuk keadaan,

\footnotetext{
${ }^{19}$ Simon Clark. TERROR VANQUISHED: The Italian Approach to Defeating Terrorism. The Center for Security Policy Studies, Schar School of Policy and Government, George Mason University. (2018). Hal: 51. E-book.
}

investigasi terhadap peristiwa-peristiwa ini sering dihambat oleh penutupan dan korupsi dalam sistem peradilan. Jadi, pemerintah Italia umumnya tidak mengetahui potensi destruktif dari kelompok Red Brigades. Selanjutnya, kelompok ini meningkatkan kegiatan mereka. Setelah pemimpin Red Brigades mulai fokus pada personel politik, seperti hakim Genoan, pemerintah Italia mulai lebih fokus untuk melawan kelompok teroris ini. Namun, pada saat itu, kelompok ini telah berhasil mengembangkan kapasitas dan kelompok mereka. ${ }^{20}$ Akibat dari ini, pemerintah Italia mulai mengarahkan perhatiannya ke Red Brigades dan mengeluarkan kebijakankebijakan. Kebijakan yang diambil oleh pemerintah Italia untuk memberantas aksi terorisme yang dilakukan oleh Red Brigades adalah sebagai berikut:

1. Membentuk Gladio yang terdiri dari sekelompok unit militer yang akan dikerahkan saat terjadi pemberontakan komunis di Italia dan berupaya mengembalikan Italia ke jalur demokratisnya.

2. Adanya kelompok polisi yang terlibat dengan nama Pubblica Sicurezza (PS) dan Armata de i Carabinieri (CC).

3. Dinas rahasia mengembangkan dua lembaga khusus yang bernama Inspektorat Jendral yang berfungsi untuk melawan aksi teroris yang disebut dengan Ispettorato General per la Lotta Contro i terror-ismo dan membentuk kelompok khusus Judiciary Police yang disebut dengan Nucleo Speciale di Polizia Quardiziaria yang berhasil menghancurkan

\footnotetext{
${ }^{20}$ James. J. F. Forest "Countering Terorism and Insurgency in the 21st Century: Italy and The Red Brigades, The Success of Repentence Policy in Counterterrorism." Praeger Security International. (2007). Hal: 356. Ebook.
} 
kelompok teroris sayap kiri, serta menangkap pendiri Red Brigades yaitu Renato Curcio dan Alberto Franceschini.

4. Mengeluarkan Undang-Undang Pentiti yang menangani ancaman teroris secara langsung untuk mencegah kejahatan dimasa depan, serta UndangUndang Pentiti mengatur tentang hukuman bagi para teroris. Hukuman bagi para teroris akan dikurangi jika mereka meninggalkan perjuangan bersenjata dan tidak bekerjasama lagi, serta memberi informasi tentang teroris. Undang-Undang Pentiti juga mengatur tentang memberikan pelatihan profesional kepada pelaku terorisme untuk dapat kembali ke masyarakat.

Karena adanya agen rahasia bentukan pemerintah pada saat itu, berhasil menangkap Curcio dan Francheschini. Walaupun begitu, para pemimpin Red Brigades lainnya kemudian menerbitkan "manifesto" doktrin pertama mereka pada tahun 1975 dengan pengembangan Resolusi Direktorat Strategis (RDS) yang membantu mendefinisikan tujuan dan sasaran organisasi. Sebenarnya, RDS mendefinisikan tujuan kelompok sebagai "serangan terkonsentrasi terhadap jantung negara karena negara adalah kumpulan imperialis dari perusahaan multinasional." Manifesto ini pada dasarnya memberikan pembenaran dan panduan yang jelas untuk beberapa kelompok. Target politik sebelumnya di Partai Kristen Demokrat Italia adalah untuk memasukkan pembunuhan tahun 1974 dari dua aktivis Gerakan Sosial Italia. Lebih penting lagi, dokumen ini membantu memperkuat alasan

${ }^{21}$ Sundquist, "Political Terrorism: An Historical Case Study of the Italian Red Brigades", 57 kelompok untuk menargetkan polisi dan otoritas hukum dalam upaya untuk meningkatkan operasi teror mereka di daerah perkotaan. Doktrin RDS yang baru juga mewakili perubahan besar dalam ideologi asli kelompok untuk mendukung kegiatan politik lokal dari gerakan pekerja yang lebih luas. Manifes kelompok pada dasarnya menyelaraskan kelompok Red Brigades menjadi gerakan militan yang lebih nasionalis yang bersekutu dengan otoritas regional dan juga Negara Italia. ${ }^{21}$

\section{Terbunuhnya Mara Cagol (1975- 1976)}

Pada 18 Februari 1975, Cagol memimpin serangan terhadap penjara Casale Monferrato, di mana Curcio berada. Pengacara Curcio juga terlibat dalam serangan ini, dia telah menggambar dan mrnyusun peta terperinci yang diberikan kepada Cagol untuk membantunya merencanakan serangan dengan bom, yang meledak tanpa hambatan. Pada saat itu terjadi, situasi di jalanan semakin memburuk, dengan munculnya bentrokan antara kelompok-kelompok bersenjata sayap kiri dan neo-fasis, yang menyebabkan timbulnya korban jiwa: empat korban pada bulan Februari, dua korban pada bulan Maret dan empat lainnya setelah kerusuhan yang meluas pada bulan April. Pemerintah bereaksi dengan mengeluarkan serangkaian kebijakan pada Mei 1975, salah satunya adalah Legge Reale, yang memberi polisi kekuatan untuk menahan tersangka hingga 96 jam. Akibatnya, Red Brigades berada di bawah tekanan internal, dengan keraguan tentang perpindahan kepemimpinan ke pendekatan yang lebih militeristik yang mengecilkan pengorganisasian pabrik yang mendukung serangan spektakuler, yang membuat 
beberapa anggota lama pergi. Kebutuhan untuk mendanai kelompok tumbuh "tetap" bawah tanah mendorong kelompok itu ke dalam kegiatan kriminal tanpa tujuan politik. Kemudian, Cagol memutuskan untuk menculik Vallarino Gancia demi mendapatkan tebusan besar, tetapi kelompok dalla Chiesa menemukan tempat persembunyiannya dan berhasil menewaskan Cagol dalam baku tembak pada 4 Juni setelah dia membunuh satu petugas dan melukai yang lain. Selanjtnya, Curcio ditangkap kembali pada 18 Januari 1976 setelah terlibat baku tembak dimana dia dan seorang perwira Carabinieri terluka. ${ }^{22}$

\section{Violent Phase (1978-1981)}

A. Penculikan Perdana Menteri Italia Aldo Moro (1978)

Pada saat sebelum terjadinya penculikan terhadap Aldo Moro, Red Brigades kembali tidak dipandang sebagai ancaman nasional bagi Pemerintah Italia; melainkan, mereka dipandang hanya sebagai organisasi teroris sayap kiri yang mengklaim mewakili warga kelas pekerja. Bahkan, kegiatan kontraterorisme masa lalu telah menargetkan kepemimpinan Red Brigades yang asli, dan telah secara efektif membunuh atau menangkap semua anggota pendiri kelompok ini. Sayangnya, terjadi reorganisasi yang membuat kelompok radikal yang lebih kecil namun lebih kuat yang tidak takut untuk melakukan kekerasan untuk lanjut melakukan aksi teror ke tingkat berikutnya. ${ }^{23}$ Di Roma, pada 16 Maret 1978, kelompok Red Brigades yang dipimpin oleh Mario Moretti, menculik Aldo Moro yang saat itu menjabat sebagai

\footnotetext{
${ }^{22}$ Clark, "TERROR VANQUISHED: The Italian Approach to Defeating Terrorism" 57-58

${ }^{23}$ Sundquist, "Political Terrorism: An Historical Case Study of the Italian Red Brigades," 59

${ }^{24}$ Bertrand, Crettez. R'egis. Deloche "An Economic Analysis of the Aldo Moro Kidnapping and Assassination." Cliometrica,
}

Perdana Menteri Italia. Mereka menahannya sebagai tahanan selama 55 hari. Pada 9 Mei 1978, mereka akhirnya membunuh Moro. Sebagai Perdana Menteri Italia, Moro adalah perwakilan tertinggi dari tradisi Politik Katolik, dan salah satu pemimpin paling otoritatif dari partai Demokrat Kristen yang berkuasa (Democrazia Cristiana, atau DC). Kelompok teroris sayap kiri yang diilhami secara ideologis oleh Marxis-Leninisme, BR sangat aktif di Italia pada 1970-an. Teerdapat klaim bahwa Red Brigades fungsi utama sebagai sarana untuk mencapai tujuan yang diinginkan oleh musuh-musuh politik Moro. ${ }^{24}$

\section{B. Penculikan Jenderal James Dozier (1981)}

Pada malam 17 Desember 1981, Brigadir Jenderal Angkatan Darat AS James L. Dozier, pejabat senior Amerika di markas NATO di Verona, Italia, diculik oleh kelompok Red Brigades. Penargetan Jenderal Dozier mematahkan pola kegiatan teroris sebelumnya di Italia; sampai saat itu kelompok teroris memusatkan tindakan mereka terhadap politisi senior Italia, industrialis, ahli hukum, penerbit surat kabar dan pejabat polisi. Pada hari-hari setelah penculikan Jenderal Dozier, banyak ancaman tambahan diterima yang tampaknya memberikan indikasi yang jelas bahwa tokoh pejabat Amerika merupakan target potensial untuk tindakan teroris. ${ }^{25}$ Tuntutan selanjutnya oleh kelompok itu termasuk kecaman terhadap pasukan militer AS bersama dengan NATO, dan lebih lanjut mempromosikan ideologi dari semua pasukan revolusioner Eropa yang

Journal of Historical Economics and Econometric History, Association Française de Cliométrie (AFC) (2009): 2-3

${ }^{25}$ Col Thomas D Phillips. "The Dozier Kidnapping: Confronting the Red Brigades.” Air \& Space Power Chronicles (2002): 1-3 
bergabung dalam pertarungan dalam skala internasional. Kelompok Red Brigades dengan cepat mengadili Jenderal Dozier dan mengeluarkan dokumen setebal 188 halaman yang menguraikan tujuan kelompok tersebut. Untungnya, polisi Italia dapat menemukan dan menyelamatkan Jenderal Dozier 42 hari setelah penculikannya. Bagi kelompok Red Brigades, kejadian ini adalah serangan besar yang berhasil dilakukan oleh kelompok mereka namun juga menjadi serangan terakhir dan akhir dari semuanya. Dengan melakukan penculikan seorang Perwira Tinggi Amerika pada akhirnya menjurus kepada tindakan dari pasukan keamanan Italia dan NATO. Akhirnya, anggota dari Red Brigades banyak yang terbunuh, ditangkap, dan memilih untuk diam-diam membubarkan diri kembali ke masyarakat dengan mencoba mengatur kembali kelompok Red Brigade. ${ }^{26}$

\section{Regrouping Phase (1982 - 1999)}

Dalam fase ini, The New Red Brigades membangun kembali kelompoknya yang kemudian dikenal sebagai Communist Combatant Party (BR/PCC) yang muncul pada tahun 1984 setelah runtuhnya organisasi asli yaitu Red Brigades. BR / PCC ini merupakan kelompok Marxis-Leninis yang ingin melanjutkan perjuangan imperialisme kapitalis dan proletariat yang tertindas. ${ }^{27}$ Tujuan akhir kelompok tersebut ialah untuk menghancuran demokrasi dan menciptakan masyarakat militan di Italia. Red Brigades juga memperluas penentangannya terhadap kebijakan luar negeri Italia yang melibatkan NATO. Beberapa oposisi ini berpusat pada gagasan bahwa Pemerintah Italia hanyalah negara boneka untuk kekuatan barat.

\footnotetext{
${ }^{26}$ Sundquist, "Political Terrorism: An Historical Case Study of the Italian Red Brigades,", 61
}

Kelompok itu kemudian dianggap orang Italia sebagai musuh ideologisnya. Akibatnya, banyak dari BR / PCC yang menargetkan pemimpin politik dan pebisnis di Italia. Komentar masa lalu oleh para pemimpin kelompok pada tahun 2002 memuji serangan teroris 11 September 2001 yang ditambahkan perhatian pada organisasi dari badan intelijen Amerika Serikat.

Namun, Departemen Luar Negeri A.S. tidak secara resmi menunjuk Red Brigades sebagai Organisasi Teroris Asing. Departemen Luar Negeri sebagai gantinya mencantumkan grup tersebut pada daftar pengawasan teroris 2002 dan 2003, dan saat ini daftar BR / PCC pada daftar "Kelompok Teroris Lain".

Berbeda dengan Red Brigades, BR / PCC tidak menjadikan penculikan sebagai sarana untuk menyebarkan ideologinya atau untuk menciptakan kecemasan di masyarakat domain. Akan tetapi organisasi ini menerapkan penggunaan taktis pembunuhan dan pemboman teroris untuk menciptakan kekacauan di masyarakat Italia setempat untuk menunjukkan lemahnya keamanan oleh pemerintah. Contoh serangan pertama yang diketahui oleh BR / PCC terjadi pada Mei 1999 ketika anggota kelompok membunuh Buruh Italia Penasihat Kementerian Massimo D'Antona. Selain itu, pada bulan April 2001, BR / PCC membom Institute for International Affairs di Roma, sebuah serangan itu, untungnya, tidak membunuh siapa pun. Tahun berikutnya di bulan Maret, grup anggota menargetkan dan membunuh Penasihat Departemen Tenaga Kerja Marco Biagi.

Meskipun aktivitas BR / PCC sudah mulai meningkat pada tahun-tahun

\footnotetext{
${ }^{27}$ David Childs. "In the Spotlight: New Red Brigades Communist Combatant Party (BR/PCC)," Center for Defense Information." CDI.org (2005): 353
} 
sebelumnya, dan 2003 terbukti menjadi titik kulminasi bagi Red Brigades dan Otoritas italia. Misalnya, pada bulan Maret seorang penjaga keamanan Italia terbunuh bersama dengan pemimpin BR / PCC, Mario Galesi, selama baku tembak di Kereta penumpang Florence. Insiden itu juga menyebabkan penangkapan pemimpin BR / PCC yang lain, Desdemona Lioce, yang telah melarikan diri dari Italia sebagai seorang pihak berwenang sejak 1995 dan telah terlibat dalam pembunuhan Massimo D'Antona pada 1999. Selain itu razia selanjutnya berlangsung Apartemen Massimo oleh polisi Italia yang menghasilkan senjata mulai dari pistol dan granat tangan ke bahan peledak tingkat tinggi yang dianggap berasal dari hubungan sebelumnya dengan Organisasi Pembebasan Palestina (PLO).

\section{Final Activity Phase (2000 - 2003)}

Peningkatan aktivitas ekstremis dengan cepat meningkatkan kekhawatiran masyarakat Italia yang mengingat hari-hari ketika kelompok Red Brigades yang asli menciptakan kekacauan di seluruh negeri. Otoritas Italia akibatnya memutuskan untuk mengintensifkan dan memperluas operasi kontraterorisme mereka terhadap BR / PCC dan jaringannya. Peningkatan operasi ini termasuk kampanye media yang kuat ditambah dengan peningkatan dana untuk pembayaran sumber. Pendekatan kontraterorisme Italia yang baru tidak hanya memungkinkan pihak berwenang untuk menciptakan penghalang yang efektif antara kelompok ekstremis dan masyarakat, tetapi juga memungkinkan polisi untuk menyusup dan menghancurkan jaringan BR / PCC secara relatif cepat. Bahkan, pada 2003, United States Congressional Issue Brief menunjukkan bahwa Italia

\footnotetext{
${ }^{28}$ Raphael Perl. "Terrorism and National Security: Issues and Trends." Congressional Research Service. United States
}

memberikan hadiah untuk program informasi bagi siapapun yang berperan penting dalam membantu menghancurkan kelompok BR / PCC di Italia. ${ }^{28}$ Taktik ini pada dasarnya memungkinkan polisi untuk mengidentifikasi anggota BR / PCC, memetakan jaringan, dan secara agresif mencegah serangan di masa depan serta menangkap semua anggota kelompok teroris yang diketahui. Upaya kontraterorisme Italia akhirnya terbayar dengan penangkapan enam anggota BR / PCC yang terhubung dengan serangan kereta penumpang pada Maret 2003. Dan terdapat dua anggota kelompok yang juga diditangkap di Kairo, Mesir pada Januari 2004, diyakini terkait dengan penculikan dan pembunuhan Aldo Moro pada tahun 1978.

Pemerintah Italia menunjukkan kemampuan dan tekad yang kuat dalam memerangi BR / PCC. Pihak berwenang secara efektif membongkar kelompok, dan memaksa penurunan keanggotaan dalam BR / PCC untuk 20 anggota yang dilaporkan.

\section{End Phase (2004)}

Pada akhirnya, kegiatan terorisme kelompok BR / PCC harus disudahi. Ini ditandai dengan apa yang terjadi pada tahun 2004. Terjadi penangkapan terhadap 2 anggota BR / PCC di Cairo, Mesir dan ini menjadi akhir dari pergerakan kelompok BR / PCC. Bersamaan dengan hal tersebut, upaya counterterrorism yang dilakukan oleh pemerintahan Italia dianggap berhasil dalam memberantas The Red Brigades / BR PCC.

\section{Tipe Terorisme}

Tipe-tipe terorisme dibedakan menjadi empat jenis yaitu insurrectionary terrorism, Loner atau issue terrorism,

Department of State, Foreign Affairs, Defense, and Trade Division, (2003). 
nationalist terrorism dan global terrorism. insurrectionary terrorism merupakan tindakan terorisme yang dilakukan disebuah negara dengan tujuan untuk melakukan perubahan. Kemudian ada Loner atau issue terrorism merupakan tindakan terorisme yang bertujuan untuk mempromosikan tentang suatu penyebab atau suatu isu. Selanjuttnya ada nationalist terrorism merupakan tindakan terorisme yang dilakukan dengan tujuan untuk menggulingkan pemerintah, serta mendapatkan kemerdekaan dan kebebasan. Terakhir ada global terrorism yang merupakan tindakan terorisme dengan memiliki tujuan untuk menimbulkan kerusakan terhadap tatanan global. ${ }^{29}$

Tindakan terorisme yang dilakukan oleh kelompok Red Brigades di Italia,

\section{KESIMPULAN}

The Red Brigades adalah suatu kelompok militant yang muncul pada 20 Oktober 1970. Kelompok Red Brigades merupakan kelompok masyarakat yang awalnya memiliki tujuan mensejahterakan masyarakat kecil, mencari keadilan dan menghilangkan kesenjangan sosial di kehidupan masyarakat asia, namun seiring berjalannya waktu dan juga pengaruh dari pihak luar menjadikan arah tujuan Red Brigades berubah dan menjadi kelompok bersenjata yang anarkis. Walaupun pihak sayap kiri pemerintahan Italia saat itu menyangkal ikut campur, tetapi klaim Red Brigades mengenai ikut campur tangannya beberapa pihak sayap kiri serta koneksi koneksi mereka menunjukkan jika mereka termasuk kedalam tipe terorisme insurrectionary terrorism dan nationalist terrorism. Dimana kelompok Red Brigades melakukan tindakan terorisme karena berawal dari kaum buruh atau pekerja yang tidak diperlakukan dengan tidak adil oleh kaum Borjuis dan pada masa itu pemerintahan Itali mulai kearah barat. Adanya hal tersebut membuat munculnya kelompok Red Brigades untuk menciptakan keadilan bagi kaum pekerja dan mempengaruhi kebijakan pemerintah supaya tidak kearah barat. Demi mewujudkan semua itu Red Brigades melakukan pemberontakan dan merasa ingin merdeka dengan melakukan berbagai tindakan terorisme seperti pencurian, penculikan, pembunuhan dan pengeboman.

memiliki pendukung dan latar belakang yang kuat. Semakin lama Red Brigades semakin berani melakukan aksi-aksi mereka bahkan dengan taktik yang matang. Bahkan mereka semakin berani beraksi setelah pemimpin dan pendirinya tertangkap, akibatnya Red Brigades mempengaruhi pemerintah Italia menjadi lebih waspada terhadap kelompokkelompok masyarakat baru serta Red Brigades menjadi salah satu sejarah kelam di Italia. Karena ini juga, pemerintah Italia akhirnya mengeluarkan berbagai macam kebijakan untuk memerangi tindakan terorisme yang dilakukan kelompok ini sampai akhirnya kelompok Red Brigades resmi membubarkan diri pada tahun 2004.

\footnotetext{
${ }^{29}$ Adityo Darmawan Sudagung. "Perjalanan Pertama: Terorisme" (Pontianak, Universitas Tanjungpura, Februari 2020)
} 


\section{DAFTAR PUSTAKA}

"Brigate Rosse and Moro Kidnapping: Secrets and Lies" http://www.robertobartali.it. Diakses $9 \quad$ Juni 2020. http://www.robertobartali.it/english.h $\underline{\mathrm{tm}}$

Childs, David. "In the Spotlight: New Red Brigades Communist Combatant Party (BR/PCC)," Center for Defense Information.” CDI.org (2005): 353

Clark, Simon. TERROR VANQUISHED: The Italian Approach to Defeating Terrorism. The Center for Security Policy Studies, Schar School of Policy and Government, George Mason University. (2018). E-book. Hal 51, 57-58.

Crettez, Bertrand. Deloche, R'egis. "An Economic Analysis of the Aldo Moro Kidnapping and Assassination." Cliometrica, Journal of Historical Economics and Econometric History, Association Française de Cliométrie (AFC) (2009): 2-3

Forest, James. J. F. "Countering Terorism and Insurgency in the 21st Century: Italy and The Red Brigades, The Success of Repentence Policy in Counterterrorism." Praeger Security International. (2007). Ebook. Hal 356

Ginsborg, Paul. A History of Contemporary Italy: Society and Politics: 19431988. Inggris: Penguin UK, 1990.

Khotibah. "Penelitian Kepustakaan." IAIN Sumatera Utara. Volume 05. No.01. (2011):38
Nasution, S. Metode Penelitian Naturalistik Kualitatif. Bandung: Tarsito, 1988.

Orsini, Alessandro, Nodes, Sarah J. Anatomy of the Red Brigades: The Religious Mind-set of Modern Terrorists. Ithaca: Cornell University Press. 2011.

Phillips, Col Thomas D. "The Dozier Kidnapping: Confronting the Red Brigades." Air \& Space Power Chronicles (2002): 1-3

Putra, Efri Aditya. "Persaingan Global Climate Coalition dan Greenpeace dalam Mempengaruhi Kebijakan Amerika Serikat Terhadap Ratifikasi Protokol Kyoto" Thesis, UMM Instutional Repository, 2016: 19-20.

Raphael Perl. "Terrorism and National Security: Issues and Trends." Congressional Research Service. United States Department of State, Foreign Affairs, Defense, and Trade Division, (2003).

"Red Brigades" britannica.com. Diakses 1 Juni 2020. https://www.britannica.com/topic/Re d-Brigades

"Remembering Aldo Moro, the former prime minister killed by terrorists during Italy's 'Years of Lead'." thelocal.it. Diakses 20 Mei 2020. https://www.thelocal.it/20180315/ital y-remembers-aldo-moro

RE, Matteo. "Colpevolezza Ed Esagerazione Nell'interpretazione Del Terrorismo Brigatista Da Parte 
Della Stampa Italiana”. (2011): 165. doi:

http://dx.doi.org/10.5209/rev_CFIT.2 $\underline{011 . v 18.38169}$

Sudagung, Adityo Darmawan. "Perjalanan Pertama: Terorisme" (Pontianak, Universitas Tanjungpura, Februari 2020)

Sundquist, Victor H. "Political Terrorism: An Historical Case Study of the Italian Red Brigades" Journal of Strategic Security (2010): 53-68. doi: http://dx.doi.org/10.5038/1944$\underline{0472.3 .3 .5}$

Surbakti, Ramlan. "Memahami Ilmu Politik." Grasindo. PT. Gramedia. (1992) E-book. Hal 109.

Swastika, Enggar. "Kebijakan Perdana Menteri Yingluck Shinawatra
Tentang Pembatalan Ekspor Beras Ke Indonesia Tahun 2011" Thesis, UMM Instutional Repository, 2016: 16.

Tarantelli, Carole Beebe. "The Italian Red Brigades and the structure and dynamics of terrorist groups" The International Journal of Psychoanalysis (2016): 545. doi: 10.1111/j.1745-8315.2010.00264.x

Waltz, Stephen M. Rational Choice and Security Studies: Rigor or Rigor Moris?. Massachusetts: MIT Press Journals, 1999

"Valle Giulia Has Taken On Mythological Stature." npr.org. Diakses 17 Mei 2020

https://www.npr.org/templates/story/ story.php?storyId=91819083 